
\title{
KERTHA WICAKSANA
}

Sarana Komunikasi Dosen dan Mahasiswa

\section{Tanggungjawab Pemerintah Dalam Pengelolaan Lingkungan Hidup Berbasis} Partisipasi Masyarakat untuk Pembangunan Daerah Bali

\author{
I Nyoman Gede Sugiartha* dan Ida Ayu Putu Widiati \\ Universitas Warmadewa, Denpasar, Bali \\ *Nyomansugiartha14@gmail.com
}

Published: 30/07/2020

How To Cite:

Sugiartha, I, N, G., Widiati, I, A, P. (2020). Tanggungjawab Pemerintah Dalam Pengelolaan Lingkungan Hidup Berbasis Partisipasi Masyarakat untuk Pembangunan Daerah Bali. KERTHA WICAKSANA: Sarana Komunikasi Dosen dan Mahasiswa. 14 (2). Pp 96 - 102. https://doi.org/10.22225/kw.14.2.1862.96-102

\begin{abstract}
Abstrak
Lingkungan hidup yang baik dan sehat merupakan hak asasi setiap warganegara Indonesia sebagaimana diamanatkan dalam Pasal 28H UUD RI 1945. Pengelolaan lingkungan yang kurang bijaksana turut memperparah penurunan kwalitas lingkungan hidup karena itu perlu dilakukan peningkatan perlindungan dan pengelolaan lingkungan hidup. Perlindungan dan pengelolaan lingkungan yang berkelanjutan merupakan tanggungjawab pemerintah beserta masyarakat. Pertanggungjawaban pemerintah dalam melakukan perlindungan dan pengelolaan lingkungan hidup merupakan fungsi pelayanan public, untuk menjamin seluruh penduduk mendapatkan lingkungan yang baik dan sehat. Maka pemerintah dapat diminta pertanggungjawabannya, baik secara administrative, perdata maupun pidana mana kala pemerintah lalai melaksanakan kewajibannya yang tidak sesuai dengan aspirasi masyarakat. Penelitian ini dikualifikasikan sebagai penelitian hukum normatif dengan menerapkan beberapa jenis pendekatan yaitu, pendekatan perundang-undangan, pendekatan konseptual, pendekatan filsafat, pendekatan sejarah, pendekatan perbandingan, pendekatan kasus termasuk pula pendekatan budaya atas dasar kearifan masyarakat lokal. Hasil penelitian menunjukan bahwa perlindungan dan pengelolaan lingkungan hidup adalah upaya mengemban tanggungjawab sangat sulit sehingga mengakibatkan terjadinya penurunan kwalitas lingkunan hidup makin nyata. Begitu pula dalam hal terjadi pencemaran dan perusakan lingkungan hidup pelaku dapat diminta pertanggungjawabannya baik secara hukum perdata maupun hukum pidana. Namun demikian penegakan lingkungan partisipatif dengan mengintegrasikan nilai-nilai yang berkembang di masyarakat dalam menjaga dan melestarikan lingkungan adalah suatu bentuk idial untuk melindungi dan melakukan pengelolaan lingkungan hidup secara bijaksana untuk mewujudkan pembangunan daerah yang berkelanjutan.
\end{abstract}

Kata kunci: Masyarakat bali, pengelolaan lingkungan, tanggungjawab pemerintah

\begin{abstract}
A good and healthy environment is a human right for every Indonesian citizen as mandated in Article $28 \mathrm{H}$ of the 1945 Constitution of Indonesia. Unwise management of the environment contributes to the deterioration in the quality of the environment because it is necessary to increase environmental protection and management. Environmental protection and sustainable management is the responsibility of the government and the community. The responsibility of the government in carrying out environmental protection and management is a function of public services, to ensure that all residents have a good and healthy environment. Then the government can be held accountable, whether administratively, civil or criminal, when the government fails to carry out its obligations that are not in accordance with the aspirations of the community. This study is qualified as a normative legal research by applying several types of approaches, namely, the legislative approach, conceptual approach, philosophical approach, historical approach, comparative approach, case approach including cultural approaches based on the wisdom of the local community.The results showed that the protection and management of the environment is an effort to assume responsibility is very difficult so that it results in a decrease in the quality of the environment is increasingly apparent. Likewise in the event of environmental pollution and damage, the perpetrators can be held responsible both in civil law and criminal law. However, participatory environmental enforcement by integrating values that develop in the community in protecting and preserving the environment is an ideal form of protecting and prudent environmental management to realize sustainable regional development.
\end{abstract}

Keywords : Balinese communities, environmental management, government responsibilities 


\section{PENDAhUluan}

Lingkungan hidup yang baik dan sehat merupakan hak asasi setiap warganegara Indonesia sebagaimana diamanatkan dalam Pasal 28H UUD RI 1945 (Fahmi, 2013). Pengelolaan lingkungan yang kurang bijaksana turut memperparah penurunan kualitas lingkungan hidup karena itu perlu dilakukan peningkatan perlindungan dan pengelolaan lingkungan hidup (Najwan, 2012). Perlindungan dan pengelolaan lingkungan hidup bertujuan mewujudkan pembangunan berkelanjutan.

Melakukan perlindungan dan pengelolaan terhadap lingkungan hidup yang baik dan sehat maka setiap pelaku dan/atau penanggung jawab usaha wajib mendapatkan izin lingkungan sesuai ketentuan hukum yang berlaku. Hal ini tertuang dalam Undang-undang Pengelolaan dan Perlindungan Lingkungan Hidup (UUPPLH) No. 32 Tahun 2009, Peraturan Pemerintah No. 27 Tahun 2012 tentang Izin Lingkungan, Peraturan Mentri Lingkungan Hidup No. 08 Tahun 2013 Tentang Tata Laksana Penilaian Dan Pemeriksaan Dokumen Lingkungan Hidup Serta Penerbitan Izin Lingkungan. Izin lingkungan adalah sesuatu yang wajib dimiliki oleh penanggungjawab usaha dan /atau kegiatan sebagai upaya pengawasan dari pemerintah dalam perlindungan dan pengelolaan lingkungan hidup (Dewi, 2012). Hukum diciptakan sebagai suatu sarana atau instrumen untuk mengatur hak-hak dan kewajiban-kewajiban subjek hukum (Kartono, 2009). Selain itu Hukum yang mengatur hubungan hukum antara pemerintah dengan warga negara adalah Hukum Administrasi Negara atau hukum perdata, tergantung dari sifat dan kedudukan pemerintah dalam melakukan tindakan hukum tersebut (Sutrisno, 2013). Ketika pemerintah melakukan tindakan hukum dalam kapasitasnya sebagai wakil dari badan hukum, maka tindakan tersebut diatur dan tunduk pada ketentuan hukum keperdataan (Fahmi, 2013), sedangkan ketika pemerintah bertindak sebagai pejabat, maka tindakan itu diatur dan tunduk pada Hukum Administrasi Negara. Bagi pelanggarnya harus dikenakan sanksi sesuai tingkat kesalahannya (Yusran, 2003).

Kepastian penerapan hukum lingkungan sulit diselesaikan maka dalam upaya memaksimalkan penegakan hukum sepatutnya didukung oleh aturan yang baik, pelaksana pihak pemerintah secara sungguh-sungguh (Soemarwoto, 1999). Masalahnya kecendrungan pemerintah Daerah membangun

fasilitas

ekonomi

dengan

mengekploitasi sumber daya alam dan lingkungan untuk mengejar Pendapatan Asli Daerah (PAD), dan kurang memperhatikan daya dukung kelestarian lingkungan Daerahnya (Pitana, 2004) dan kurang taat aturan. Berdasarkan uraian latar belakang di atas, sangat menarik dikaji persoalan mengenai pertanggungjawaban pemerintah dalam pengelolaan lingkungan hidup yang tidak sesuai dengan aspirasi masyarakat dan akibat hukum terhadap pemerintah atas keputusan dalam pengelolaan lingkungan hidup yang tidak sesuai dengan partisipasi masyarakat di Bali.

\section{METODE}

Jenis penelitian yang dilakukan dalam rangka penulisan ini adalah penelitian hukum gabungan antaran Normatif dan Empirik (Mixed Method). Penelitian hukum jenis ini mengkonsepsikan hukum sebagai apa yang tertulis dalam peraturan perundang-undangan (law in books) atau hukum dikonsepsikan sebagai kaidah atau norma yang merupakan patokan berprilaku manusia yang dianggap pantas (Amiruddin \& Asikin, 2004). Pendekatan kasus (case approach) dalam penelitian normatif bertujuan untuk mempelajari penerapan norma-norma atau kaidah hukum yang dilakukan dalam praktik hukum, terutama mengenai kasus-kasus yang telah diputus sebagaimana yang dapat dilihat dari yurisprudensi terhadap perkara yang menjadi focus penelitian (Ibrahim, 2006). Selanjutnya Pendekatan masalah yang digunakan meliputi beberapa jenis pendekatan yaitu Pendekatan Perundangundangan(Statute Approach),Pendekatan koseptual (conceptual approach), Pendekatan Kasus (case approach), Pendekatan Historis (Historical Approach), Pendekatan Perbandingan (Comparative Approach).

\section{III.HASIL DAN PEMBAHASAN}

Pertanggungjawaban Hukum Terhadap Pemerintah Dalam Pengelolaan Lingkungan Hidup Yang Tidak Sesuai Dengan Aspirasi Masyarakat

Melakukan berbagai tindakan (termasuk tindakan hukum) pemerintah harus bersandar pada asas legalitas. Tindakan hukum mengandung makna penggunaan kewenangan dan didalamnya tersirat adanya kewajiban pertanggungjawaban. Tanggung jawab negara terhadap warga negara atau pihak ketiga dianut oleh hampir semua negara. Perspektif hukum publik, tindakan hukum pemerintahan itu selanjutnya dituangkan dalam dan dipergunakan beberapa instrumen hukum dan kebijakan seperti peraturan perundang-undangan, 
peraturan kebijakan, dan keputusan (Dewi, 2012). Disamping itu, pemerintah juga sering menggunakan instrumen hukum keperdataan seperti perjanjian dalam menjalankan tugas-tugas pemerintahan. Setiap penggunaan wewenang dan penerapan instrumen hukum oleh pejabat pemerintahn pasti menimbulkan akibat hukum, karena memang tujuannya dimaksudkan adalah untuk menciptakan hubungan hukum dan akibat hukum.

Pejabat adalah seorang yang karena tugas dan wewenangnya bertindak sebagai wakil dari jabatan, yang melakukan perbuatan untuk dan atas nama jabatan. Sementara seseorang itu disebut atau dikategorikan sebagai pejabat adalah ketika ia menjalankan kewenangan untuk atau atas nama jabatan. Berdasarkan keterangan di atas, tampak bahwa tindakan hukum yang dijalankan oleh pejabat dalam rangka menjalankan kewenangan jabatan atau melakukan tindakan hukum untuk dan atas nama jabatan, maka tindakannya itu dikategorikan sebagai tindakan hukum jabatan.

Mengenai pertanggungjawaban pejabat ada dua teori yang dikemukakan oleh Kraenburg dan Vegting, yaitu; pertama, fautes personalles, yaitu teori yang menyatakan bahwa kerugian terhadap pihak ketiga itu dibebankan kepada pejabat yang karena tindakannya itu telah menimbulkan kerugian, kedua, fautes de services, yaitu teori yang menyatakan bahwa kerugian terhadap pihak ketiga itu dibebankan pada instansi dari pejabat yang bersangkutan.

Mengutip pendapat Logeman, hak dan kewajiban berjalan terus, tidak peduli dengan penggantian pejabat. Berdasarkan keterangan tersebut jelaslah bahwa pemikul tanggung jawab itu adalah jabatan. Oleh karena itu, ganti rugi juga dibebankan kepada instansi/jabatan, bukan kepada pejabat selaku pribadi. Sebagaimana dikatakan Kranenburg dan Vegting bahwa pertanggungjawaban dibebankan kepada korporasi (instansi, jabatan) jika suatu perbuatan melawan hukum yang dilakukan oleh pejabat itu bersifat objektif, dan pejabat yang bersangkutan tidak dibebani tanggungjawab jika tidak ada kesalahan subjektif. Sebaliknya pejabat atau pegawai itu dibebani tanggung jawab ketika ia melakukan kesalahan subjektif. Untuk perbuatan melanggar hukum lainnya, hanya wakil yang bertanggungjawab sepenuhnya; ia telah menyalahgunakan situasi, dimana ia berada selaku wakil, dengan melakukan tindakan amoralnya sendiri terhadap kepentingan pihak ketiga. Dalam hal demikian, pejabat tersebut telah melakukan kesalahan subjektif atau melakukan mal administrasi.

Pertanggungjawaban pemerintah dalam hal keputusannya tidak sesuai aspirasi masyarakat dalam hukum lingkungan telah diatur dalam UUPPLH khususnya dalam Pasal 91 tentang Hak Gugat Masyarakat dalam hal masyarakat dirugikan, Pasal 92 tentang Hak gugat masyarakat yang tergabung dalam Organisasi Lingkungan Hidup dan Pasal 93 UUPPLH memberikan hak setiap orang dalam masyarakat dapat mengajukan gugatan administrasi terhadap keputusan pemerintah apabila :

badan atau pejabat tata usaha negara menerbitkan izin lingkungan kepada usaha dan/atau kegiatan yang wajib amdal tetapi tidak dilengkapi dengan dokumen amdal;

badan atau pejabat tata usaha negara menerbitkan izin lingkungan kepada kegiatan yang wajib UKL-UPL, tetapi tidak dilengkapi dengan dokumen UKL-UPL;dan/atau

badan atau pejabat tata usaha negara yang menerbitkan izin usaha dan/atau kegiatan yang tidak dilengkapi dengan izin lingkungan.

Penegakan hukum pidana dalam penegakan hukum lingkungan hidup dalam UUPLH No. 23 Tahun 1997 hanya sebagai ultimum remidium, sehingga isi penegakan sanksi hukum pidananya tidak dominan. Asas ultimum remedium dalam penjelasan itu, ternyata kurang jelas dan tegas. Penjelasan umum sesungguhnya merupakan upaya memperjelas makna dari konsideran suatu Undang-undang. Konsideran mengandung nilainilai filosofis dari suatu Undang-undang (Araya, 2013). Dengan demikian sesungguhnya penjelasan umum merupakan suatu upaya dari pembentuk Undang-undang atau legislator untuk mempertegas nilai-nilai filosofis yang terdapat dalam suatu konsideran. Nilai-nilai filosofi dalam konsideran suatu Undang-undang terkonkritisasi pada batang tubuh berupa Pasal-pasal dari Undang-undang tersebut (Machmud, 2011). Pada dasarnya (basic), pengertian pemidana dalam suatu peraturan perundang-undangan sangat penting. Hal ini telah dimasukkan dalam Undangundang penegakan hukum lingkungan dengan adanya ketentuan hukum pidana yang tercakup dalam Undang-undang tentang pengelolaan lingkungan hidup. Undang-Undang Nomor 32 Tahun 2009 tentang Pengelolaan Lingkungan 
Hidup (UUPLH) telah memasukkan ketentuan ketentuan hukum pidananya dalam Bab XV, yang terdiridari 23 Pasal, dimulai dari Pasal 97 sampai dengan Pasal 120 UUPPLH.

Berkaitan dengan hal itu tanggungjawab pemerintah dalam pengambilan keputusannya tidak sesuai dengan aspirasi masyarakat dan menyebabkan kerugian atau luka berat dan/atau meninggal dapat dituntut secara hukum pidana. Hal itu diatur dalam Pasal 111 dan Pasal 112 UU No. 32 Tahun 2009 tentang PPLH, Pasal 111 mengatur tentang (1)Pejabat pemberi izin lingkungan yang menerbitkan izin lingkungan tanpa dilengkapi dengan amdal atau UKLUPL sebagaimana dimaksud dalam Pasal 37 ayat (1) dipidana dengan pidana penjara paling lama 3 (tiga) tahun dan denda paling banyak Rp.3.000.000.000,00 (tiga miliar rupiah). Dan ayat (2) Pejabat pemberi izin usaha dan/atau kegiatan yang menerbitkan izin usaha dan/atau kegiatan tanpa dilengkapi dengan izin lingkungan sebagaimana dimaksud dalam Pasal 40 ayat (1) dipidana dengan pidana penjara paling lama 3 (tiga) tahun dan denda paling banyak Rp 3.000.000.000,00 (Tiga Milyar Rupiah).

Selanjutnya dalam pasal 112 mengatur mengenai Setiap pejabat berwenang yang dengan sengaja tidak melakukan pengawasan terhadap ketaatan penanggung jawab usaha dan/atau kegiatan terhadap peraturan perundang- undangan dan izin lingkungan sebagaimana dimaksud dalam Pasal 71 dan Pasal 72, yang mengakibatkan terjadinya pencemaran dan/atau kerusakan lingkungan yang mengakibatkan hilangnya nyawa manusia, dipidana dengan pidana penjara paling lama 1 (satu) tahun atau denda paling banyak Rp500.000.000,00 (lima ratus juta rupiah).

Pengaturan dalam ketentuan ini, bertujuan preventif melalui pengawasan dan pembinaan maupun represif melalui penerapan sanksi hukum lingkungan. Tindak pidana yang diatur di dalam Undang-Undang No. 32 Tahun 2009 bukan delik aduan melainkan sebagai delik biasa. Konsekuensinya penyidik bersikap aktif dengan langsung melaksanakan tugasnya untuk melakukan serangkaian tindakan seperti penangkapan dan penahanan kepada pelakunya tanpa menunggu adanya pengaduan terlebih dahulu dari pihak korban (Supramono, 2013). Dalam melakukan penangkapan dan penahanan, penyidik pejabat pegawai negeri sipil berkoordinasi dengan penyidik pejabat polisi Negara Republik Indonesia (Pasal 94 ayat (3) UUPLH). Setelah pelakunya selesai proses penyidikan, kemudian dibawa ke kejaksaan untuk dilakukan penuntutan perkara selanjutnya diserahkan ke pengadilan untuk disidangkan. Di persidangan untuk menentukan bersalah tidaknya pelaku dengan menggunakan alat-alat bukti yang sah menurut Undang-undang.

Dalam Pasal 6 ayat (1) KUHAP dikenal ada 2 (dua) penyidik tindak pidana yaitu penyidik Polri dan penyidik Pegawai Negeri Sipil (PNS). Penyidik Polri sebagai penyidik umum untuk semua tindak pidana, sedangkan penyidik PNS adalah penyidik khusus tindak pidana di bidang tertentu yang ditentukan oleh Undang-undang (Luthan, 2009). Untuk penyidik tindak pidana di bidang lingkungan hidup, Pasal 94 ayat (1) UUPPLH menyebutkan, selain penyidik pejabat Polisi Negara Republik Indonesia, pejabat sebagai pegawai negeri sipil tertentu di lingkungan instansi pemerintah yang lingkup tugas dan tanggungjawabnya di bidang perlindungan dan pengelolaan lingkungan hidup diberi wewenang sebagai penyidik sebagaimana dimaksud dalam hukum acara pidana untuk melakukan penyidikan tindak pidana lingkungan hidup. Ada dua penyidik yang berwenang, yaitu penyidik Polri dan Penyidik PNS bertugas menyidik di bidang lingkungan hidup (penyidik PNSLH) (Hakim, 2007) (Arief, 2007). Peran Hukum Pidana Dalam Pengelolaan Lingkungan Hidup sebagaimana yang dimaksud Peran Hukum Pidana yaitu kedudukan (status) hukum pidana dalam menjalankan tugasnya untuk mewujudkan tujuan dari hukum pidana yakni untuk melindungi masyarakat dari kejahatan (Muladi, 1998:28). Penegakan hukum lingkungan hidup dapat dimaknai bahwa hukum pidana berperan sebagai ultimum remedium. Peran hukum pidana dalam hukum lingkungan hidup harus memperhatikan asas-asas termasuk asas subsidiaritas. Sesuai dengan pendapat Sutrisno, bahwa perlindungan hukum sebagai instrumen (alat) "social control" fungsi hukum pidana dapat bermakna sebagai "subsidiaritas" artinya hukum pidana hendaknya baru digunakan apabila usaha-usaha lain yakni dalam penegakan hukum lingkungan hidup telah digunakan sangsi hukum administrasi tidak dipatuhi,atau pelanggaran dilakukan lebih dari satu kali (Sutrisno, 2013). Namun disamping itu, hukum pidana juga dapat berperan sebagai primum remedium yakni sebagai upaya pertama dalam penegakan hukum lingkungan, jika hukum 
administrasi dan/atau hukum perdata, kurang memadai. Oleh sebab itu, hukum pidana merupakan senjata pamungkas bagi penegak hukum lingkungan. Penerapan asas subsidiaritas yang pernah dilakukan penegak hukum (hakim) dapat dilihat pada kasus pencemaran teluk buyat di Manado dengan nomor register perkara No.284/Pid.B/2005/PN.MDO.

Jika melihat kasus Teluk Buyat di atas, tepatlah jika hakim memvonis bebas para terdakwa. Hal itu dikarenakan dalam proses penegakan hukumnya, belum ada penegakan hukum administrasi. Kemudian dari pertimbangan tersebut di atas, menyatakan bahwa telah tercapai perdamaian dalam proses hukum perdata sehingga seharusnya perkara tersebut harus berhenti pada proses hukum perdata dan tidak layak dilanjutkan ke proses hukum pidana. Penegakan hukum lingkungan yang menggunakan hukum pidana sebagai primum remedium dapat dilihat dalam putusan hakim dengan register perkara nomor:1215/Pid.SusLH/2016/PN.Pbr. Putusan dibaca pada pada 20 Pebruari 2017. Putusan hakim tersebut, dapat dilihat bahwa hakim menggunakan hukum pidana sebagai primum remedium (sebagai upaya hukum pertama).

Primum remedium ( hukum pidana sebagai upaya hukum pertama) yang merupakan perkembangan dari ultimum remedium yang diharapkan dengan adanya asas atau prinsip primum remedium mampu mengatasi masalahmasalah yang dihadapi dalam penggunaan hukum pidana. Pada situasi tertentu hukum pidana dapat digunakan sebagai senjata pertama. ketika instrumen hukum lain yakni hukum perdata dan/ atau hukum administrasi dianggap tidak akan mampu mengatasi kejahatan dibidang lingkungan yang dilakukan oleh pelaku maka di sinilah hukum pidana berperan sebagai primum remedium.

\section{Akibat hukum terhadap pemerintah atas keputusan dalam pengelolaan lingkungan hidup yang tidak sesuai dengan partisipasi masyarakat di Bali.}

Ada beberapa hal yang menjadi alasan warga negara harus mendapat perlindungan hukum dari tindakan pemerintah, sebagai bentuk pertanggung jawaban memberi perlindungan masyarakat yaitu:

Karena dalam berbagai hal warga negara dan badan hukum perdata tergantung pada keputusankeputusan pemerintah, seperti kebutuhan terhadap izin yang diperlukan untuk usaha perdagangan, perusahaan atau pertambangan. Karena itu warga negara dan badan hukum perdata perlu mendapat perlindungan hukum.

Hubungan antara pemerintah dan warga negara tidak berjalan dalam posisi sejajar, dan warga negara berada di pihak lemah dalam hal ini.

Berbagai perselisihan warga negara dengan pemerintah berkenan dengan keputusan, sebagai instrumen pemerintah yang memiliki kewenangan bersifat sepihak dalam menentukan intervensi terhadap kehidupan warga negara.

Di Indonesia perlindungan hukum bagi rakyat akibat tindakan hukum pemerintah ada beberapa kemungkinan, tergantung dari instrumen hukum yang digunakan pemerintah. Instrumen hukum pemerintah yang lazim digunakan adalah peraturan perundang-undangan dan keputusan. Perlindungan hukum akibat dikeluarkannya peraturan perundang-undangan ditempuh melalui Mahkamah Agung, dengan cara hak uji materiil, sesuai dengan Pasal 5 ayat (2) Tap MPR No. III/ MPR/2000 tentang Sumber Hukum dan Tata Urutan Peraturan Perundang-undangan, yang menegaskan bahwa "Mahkamah Agung berwenang menguji peraturan perundangundangan di bawah undang-undang".

Khusus mengenai peraturan perundangundangan tingkat daerah, pembatalan sering diartikan dalam pembatalan secara spontan, yakni pembatalan atas dasar inisiatif dari organ yang berwenang menyatakan pembatalan, tanpa melalui proses peradilan. Pasal 145 UU No. 32 Tahun 2004 tentang Pemerintahan Daerah terdapat ketentuan sebagai berikut:

Perda disampaikan kepada pemerintah paling lama 7 hari setelah di tetapkan.

Perda sebagaimana dimaksud ayat (1) yang bertentangan dengan kepentingan umum dan/atau peraturan perundang-undangan yang lebih tinggi dapat dibatalkan oleh pemerintah.

Keputusan pembatalan Perda sebagaimana dimaksud pada ayat (2) ditetapkan dengan Peraturan Presiden paling lama 60 hari sejak di terimanya Perda sebagaimana dimaksud ayat (1).

Paling lama 7 hari setelah keputusan pembatalan sebagaimana dimaksud pada ayat (3), kepala daerah harus memberhentikan pelaksanaan Perda dan selanjutnya DPRD bersama kepala daerah mencabut Perda dimaksud. 
Apabila Provinsi/kabupaten/kota tidak dapat menerima keputusan pembatalan Perda sebagaimana dimaksud pada ayat (3) dengan alasan yang dapat dibenarkan oleh peraturan perundang-undangan, kepala daerah dapat mengajukan keberatan kepada Mahkamah Agung.

Apabila keberatan sebagaimana dimaksud ayat (5) dikabulkan sebagian atau seluruhnya, putusan Mahkamah Agung tersebut menyatakan Peraturan Presiden menjadi batal dan tidak mempunyai kekuatan hukum.

Apabila Pemerintah tidak mengeluarkan Peraturan Presiden untuk membatalkan Perda sebagaimana dimaksud pada ayat (3), Perda tersebut dinyatakan berlaku.

Berdasarkan ketentuan tersebut, tampak bahwa peraturan perundang-undangan tingkat daerah mempunyai mekanisme hak uji materil yang berbeda dengan peraturan perundangundangan tingkat pusat, yaitu di tempuh melalui jalur pemerintahan dalam bentuk penundaan atau pembatalan, sebelum ditempuh melalui Mahkamah Agung.

Perlindungan hukum akibat dikeluarkannya keputusan ditempuh melalui dua kemungkinan, yaitu peradilan hukum administrasi dan upaya hukum administrasif. Ada perbedaan antara peradilan hukum administrasi dan upaya administratif adalah kata peradilan menunjukkan bahwa hal ini menyangkut proses peradilan pada pemerintahan melalui instansi yang merdeka.

Berdasarkan UU No. 5 Tahun 1986 tentang Peradilan Tata Usaha Negara perlindungan hukum akibat dikeluarkannya keputusan dapat ditempuh melalui dua jalur, yaitu melalui upaya administratif dan melalui PTUN. Dalam Pasal 48 di tegaskan sebagai berikut:

Dalam hal suatu Badan atau Pejabat TUN diberi wewenang oleh atau berdasarkan peraturan perundang-undangan untuk menyelesaikan secara administratif sengketa tata usaha negara tertentu, maka sengketa tata usaha negara tersebut harus diselesaikan melalui upaya administratif yang tersedia.

Pengadilan baru berwenang memeriksa, memutus dan menyelesaikan sengketa tata usaha negara sebagaimana dimaksud ayat (1) jika seluruh upaya administratif yang bersangkutan telah digunakan.

Ada empat unsur sanksi dalam hukum administrasi negara, yaitu alat kekuasaan, bersifat hukum publik, digunakan oleh pemerintah, dan sebagai reaksi atas ketidak patuhan. Ditinjau dari segi sasarannya, dalam hukum administrasi negara dikenal ada dua jenis sanksi, yaitu sanksi reparatoir dan sanksi punitif. Sanksi reparatoir adalah sanksi yang diberikan sebagai reaksi atas pelanggaran norma, yang ditujukan untuk mengembalikan pada kondisi semula sebelum terjadi pelanggaran. Sedangkan sanksi punitif adalah sanksi yang semata-mata ditujukan untuk memberikan hukuman pada seseorang. Selain itu ada juga yang disebut sebagai sanksi regresif, yaitu sanksi yang diterapkan sebagai reaksi atas ketidak patuhan.

\section{IV.SIMPULAN}

Pertanggungjawaban pemerintah dalam pengelolaan lingkungan hidup yang tidak sesuai dengan aspirasi masyarakat, dapat berupa pertanggungjawaban administrasi, perdata maupun pidana. Pertanggungjawaban pemerintah dari administrasi Berdasarkan keputusan tersebut.asarkan UU No. 9 tahun 2004 tentang Perubahan UU No. 5 tahun 1986 tentang PTUN. Pertanggungjawaban perdata berdasarkan pada Pasal 1365 KUHPerdata, yang intinya memuat : "tiap perbuatan melanggar hukum, yang membawa kerugian kepada orang lain, mewajibkan orang yang karena salahnya menerbitkan kerugian itu, mengganti kerugian tersebut." Ketentuan ini telah mengalami pergeseran penafsiran, sebagaimana tampak dari beberapa yurisprudensi. Konsep yang mengetengahkan kriteria kepentingan hukum yang dilanggar oleh pemerintah dapat digugat. Berkaitan dengan hal itu tanggungjawab pemerintah dalam pengambilan keputusannya tidak sesuai dengan aspirasi masyarakat dan menyebabkan kerugian atau luka berat dan/atau meninggal dapat dituntut secara hukum pidana. Hal itu diatur dalam Pasal 111 dan Pasal 112 UU No. 32 Tahun 2009 tentang PPLH,

Akibat hukum terhadap pemerintah atas keputusan dalam pengelolaan lingkungan hidup yang tidak sesuai dengan partisipasi masyarakat di Bali. UUPPLH No. 32 Tahun 2009, menyediakan Jalur hukum, administrasi, jalur hukum perdata dan jalur hukum pidana, penyelesaian diluar sidang pengadilan yang diatur dalam Pasal 85, Pasal 86 dan di pengadilan terkait ganti rugi, pemulihan lingkungan dan tindakan lain. Sengketa hukum di Bali juda dapat diselesaikan berdasarkan Perda Propinsi Bali, berkaitan dengan Akibat hukum pemerintah 
dalam hal keputusannya tidak sesuai aspirasi masyarakat dalam hukum lingkunganhak gugat diatur dalam Pasal 91 dan Pasal 92 UUPPLH No. 32 Tahun 2009, tentang Hak gugat masyarakat yang tergabung dalam Organisasi Lingkungan Hidup dan Pasal 93 UUPPLH memberikan hak setiap orang dalam masyarakat dapat mengajukan gugatan administrasi terhadap keputusan pemerintah.

\section{DAFTAR PUSTAKA}

Amiruddin, \& Asikin, Z. (2004). Pengantar Metode Penelitian Hukum. Jakarta: PT. Raja Grafindo.

Araya, Y. (2013). Penegakan Hukum Lingkungan Hidup di Tengah Pesatnya Pembangunan Nasional. Jurnal Legislasi Indonesia, 10(1). Retrieved from http://e-jurnal.peraturan.go.id/ index.php/jli/index

Arief, B. N. (2007). Diskusi Pakar"Studi atas Kejahatan Undang dan Inisiatif Kodifikasi ke dalam Rancangan Perubahan Lingkungan Hidup dan Sumber Daya Alam dalam Berbagai Undang-Undang.

Dewi, D. A. S. (2012). Konsep Pengelolaan Lingkungan Hidup, Menuju Kemakmuran Masyarakat. Jurnal Fakultas Hukum, 1(1). Retrieved from https://docplayer.info/44214618 -Konsep-pengelolaan-lingkungan-hidupmenuju-kemakmuran-masyarakat-oleh-dyahadriantini-sintha-dewi-abstrak.html

Fahmi, S. (2013). Asas Tanggung Jawab Negara Sebagai Dasar Pelaksanaan Perlindungan dan Pengelolaan Lingkungan Hidup. Jurnal Hukum, 18(2). Retrieved from https:// docplayer.info/31681608-Asas-tanggung-jawab -negara-sebagai-dasar-pelaksanaanperlindungan-dan-pengelolaan-lingkunganhidup.html

Hakim, A. (2007). Narkoba Bahaya Dan Penanggulanganya. Jember: Penerbit jember.

Ibrahim, J. (2006). Teori dan metodelogi penelitian hukum normative. Malang: Bayumedia Publishing.

Kartono. (2009). Penegakan Hukum Lingkungan Administratif Dalam Undang-Undang Perlindungan dan Pengelolaan Lingkungan Hidup. Jurnal Dinamika Hukum, 9(3). Retrieved from http:// dinamikahukum.fh.unsoed.ac.id/index.php/ JDH/article/view/236

Luthan, S. (2009). Asas dan Kriteria Kriminalisasi. Jurnal Hukum, 16(1). Retrieved from http:// dinamikahukum.fh.unsoed.ac.id/index.php/ $\mathrm{JDH} /$ article/view/236

Machmud, S. (2011). Penegakan Hukum Lingkungan Indonesia. Yogyakarta: Graha Ilmu.

Najwan, J. (2012). Perlindungan dan Pengelolaan
Lingkung-an Hidup dJalam Perspektif Hukum Islam. Inovatif: Jur-Nal Ilmu Hukum, 2(4). Retrieved from https://online-journal.unja.ac.id/ jimih/article/view/366

Pitana. (2004). Memperjuangkan Otonomi Daerah:Mencegah Sandyakalaning Pariwisata Bali. Denpasar: Pustaka Bali Post.

Soemarwoto, O. (1999). Analisis Mengenai Dampak Lingkungan. Yogyakarta: Gadjah Mada University Press.

Supramono, G. (2013). Penyelesaian Sengketa Lingkungan Hidup di Indonesia. Jakarta: Rineka Cipta.

Sutrisno. (2013). Politik Hukum Perlindungan dan Pengelolaan Lingkungan Hidup. Jurnal Hukum, 18(3). Retrieved from https:// docplayer.info/31681608-Asas-tanggung-jawab -negara-sebagai-dasar-pelaksanaanperlindungan-dan-pengelolaan-lingkunganhidup.html

Yusran, H. R. (2003). Pengelolaan Sumber Daya Alam Dan Otonomi Daerah, Perspektif Kebijakan Dan Evaluasi Ekonomi. Jatinangor: Alqaprint. 